\title{
Konstruksi Sosial Penerimaan Transgender
}

\author{
Giovanni Chendra, Diah Ayu Candraingrum \\ giovannichendra@gmail.com,diahc@fikom.untar.ac.id
}

Fakultas Ilmu Komunikasi Universitas Tarumanagara

\begin{abstract}
Within the community there are several deviations with different categories. One of the deviations in society related to gender can be recognized through the transgender phenomenon. The term transgender is given to individuals who feel that their gender identity is different from their own identity, so that they look and have a lifestyle with a gender that is felt to be in accordance with their identity, whether or not there is a sex change operation. This research focuses on the social construction of transgender acceptance in some of the Muslim community in South Jakarta. Therefore, this study aims to determine how transgender people can be accepted in the Muslim community in Indonesia with social construction. This type of research uses qualitative research and phenomenological methods. Researchers collected data through interviews with transgender people and religious experts. After conducting interviews, the authors concluded that with regular interactions and meetings, society would be able to accept transgender people by getting to know the person more deeply and going through the process.
\end{abstract}

Keywords: moslem, social construction, transgender

\begin{abstract}
Abstrak
Di dalam lingkup masyarakat terdapat beberapa penyimpangan dengan kategori yang berbeda-beda. Salah satu penyimpangan di masyarakat terkait jenis kelamin dapat dikenal melalui fenomena transgender. Istilah transgender diberikan kepada individu yang merasa bahwa identitas kelaminnya berbeda dengan identitas dirinya, sehingga mereka berpenampilan dan memiliki gaya hidup dengan kelamin yang dirasakan sesuai dengan identitas dirinya, dengan adanya maupun tidak adanya operasi penggantian kelamin. Penelitian ini berpusat terhadap konstruksi sosial penerimaan transgender pada beberapa masyarakat beragama Islam di Jakarta Selatan. Maka dari itu, penelitian ini bertujuan untuk mengetahui bagaimana kaum transgender dapat diterima pada beberapa masyarakat beragama Islam di Indonesia dengan konstruksi sosial. Jenis penelitian ini menggunakan penelitian kualitatif dan metode fenomenologi. Peneliti mengumpulkan data melalui wawancara dengan kaum transgender dan ahli agama. Setelah melakukan wawancara, penulis menyimpulkan bahwa dengan adanya interaksi dan pertemuan secara berkala, maka masyarakat akan bisa menerima transgender dengan mengenal orang itu lebih dalam lagi dan melewati prosesnya.
\end{abstract}

Kata Kunci: agama islam, konstruksi sosial, transgender

\section{Pendahuluan}

Salah satu penyimpangan di masyarakat terkait jenis kelamin dapat dikenal melaluui fenomena transgender. Istilah transgender diberikan kepada individu yang merasa bahwa identitas kelaminnya berbeda dengan identitas dirinya, sehingga mereka berpenampilan dan memiliki gaya hidup dengan kelamin yang dirasakan sesuai dengan identitas dirinya, dengan adanya maupun tidak adanya operasi penggantian kelamin (Praptoraharjo dkk, 2016). Transgender sendiri tidak semata- 
mata mengacu kepada orientasi ataupun seksual. Oleh karena itu, ketertarikan seksual mereka tidak berpengaruh dalam identitas diri sebagai transgender. Hal ini yang menyebabkan para transgender berbeda dengan gay atau lesbian dalam mengenali identitas diri mereka (Boellstorff dalam Praptoraharjo, dkk, 2016).

Transgender dianggap melanggar struktur normatif terkait apa yang dianggap baik, apa yang seharusmya, dan apa yang sesuai kepercayaan. Aturan normative ini menyangkut aspek kehidupan ekonomi, sosial, politik, agama, budaya, dan hukum. Oleh karena itu, seringkali para transgender mendapat perlakuan diskriminasi yang penuh dengan stigma buruk. Ketika mayoritas penduduk Indonesia menganut agama Muslim yang memiliki sudut pandang tertentu terhadap transgender, tidak lazim bahwa penolakan muncul terhadap transgender muslim. Namun kenyataannya, kaum transgender sudah menjadi bagian dari budaya lokal.

Transgender yang sudah diterima dalam kehadiran budaya sudah melalui proses konstruksi sosial. Menurut Berger dan Luckmann dalam Dharma (2018), agama merupakan bagian penting dari kebudayaan yang diciptakan dalam konstruksi sosial. Melalui data yang telah di dapat tersebut maka bisa di tarik rumusan masalahnya yaitu bagaimana konstruksi sosial kaum transgender dapat diterima masyarakat beragama islam di Indonesia? Berdasarkan tema yang diangkat, penulis menjabarkan tujuan inti penelitian untuk mengetahui bagaimana kaum transgender dapat diterima di masyarakat beragama Islam di Indonesia dengan konstruksi sosial.

\section{Metode Penelitian}

Penelitian ini memakai metedologi fenomenologi. Riset fenomenologi wajib bisa menyimpulkan makna umum yang ada dari pengalaman hidup para informan terkait fenomena atau konsep. Peneliti mengumpulkan data yang telah dikumpulkannya dari orang-orang yang telah menjalani fenomena tersebut dan membangun deskripsi gabungan tentang esensi dari pengalaman tersebut bagi semua identitas (Kholifah dan Suyadnya, 2018:121).

Metode pengumpulan data yang digunakan untuk melakukan penelitian ini adalah wawancara, observasi, dan studi kepustakaan. Wawancara adalah kegiatan yang bertujuan mendapatkan informasi tentang sebuah tema atau konsep yang di dalami dalam penelitian. Wawancara adalah proses bukti kepada informasi atau keterangan yang di dapat dengan teknik sebelumnya (Sujawerni, 2019:31). Menurut Myers wawancara dilakukan untuk peneliti menggali data secara mendalam mengenai suatu hal dalam partisipan (Sarosa, 2017:47). Hasil wawancara adalah buah pikir atau pengalaman partisipan kepada sesuatu hal (Sarosa, 2017:48).

Terdapat dua jenis observasi atau pengamatan yaitu pengamatan secara umum dan pengamatan berbeda partisipasif. Peneliti dapat ikut dalam kehidupan sehari-hari partisipan tapi tidak ikut campur tangan dalam kegaiatan partisipan dalam hal apapun itu. Pengamatan partisipasif memiliki makna yang berarti peneliti turut ikut berpartisipasi dalam kegiatan sehari-hari si partisipan (Sarosa, 2017:61). Observasi adalah kegiatan yang mendapatkan informasi untuk menampilkan gambaran yang sebenar-benarnya pada kejadian untuk menjawab rumusan masalah penelitian, untuk membantu memahami tingkah laku individu dan melakukan pengukuran pada aspek tertentu (Sujawerni, 2019:32).

Menurut Nazir, studi kepustakaan untuk memahami ilmu yang bersinggungan dengan penelitian serta mencegah terjadinya penerbitan yang tidak diinginkan (Nazir, 2013:93). Tujuannya agar mencegah terjadinya plagiat yang tidak diinginkan. 
Selain itu studi dokumen ialah pengumpulan data dalam jumlah yang besar dan tersimpan dalam bentuk dokumentasi. Sebagian data biasanya berbentuk arsip, foto, jurnal kegiatan, arsip, dan surat (Sujarweni, 2019:33). Dokumen yang dimaksud biasanya segala hal catatan berbentuk hardcopy maupun softcopy (Sarosa, 2017:65).

Pengolahan data kualitatif bertujuan untuk mengubah data yang belum didalami yang jumlahnya sangat banyak untuk menjadi data yang lebih mudah dipahami dan didalami. Analisis data bertujuan untuk mengubah data-data yang sudah di teliti menjadi sesuatu makna yang bermanfaat bagi peneliti dan pembaca penelitian tersebut (Sarosa, 2017:74).

\section{Hasil Temuan dan Diskusi}

Penerimaan kaum transgender ini memiliki banyak permasalahan. Narasumber C, Batara, yang awalnya mengalami penolakan dari orang terdekatnya yaitu keluarganya sendiri, sampai ia keluar dari rumah karena kurang diterima di keluarganya sendiri.

Permasalahan ini tidak hanya ada di keluarga, dia juga sampai beribadah di rumahnya bukan di tempat ibadah karena dia menggangap dirinya berbeda. Meskipun begitu Batara sendiri mengakui memiliki banyak teman yang masih bersedia menerima apa adanya. Adik dari Batara sudah menerima meskipun sulit untuk diterima awalnya "Bukan nerima lagi malah, kita udah support banget pokoknya apapun yang bikin dia bahagia aja" ucap adik dari seorang transgender Batara (Putri, Desember 2020).

Berbeda dengan yang dialami Batara, narasumber A, Firman seorang transgender, tidak mengalami penolakan dari keluarga maupun lingkungan sosial lainnya. Bahkan di tempat kerjanya banyak rekan menerima orang-orang seperti Firman, bahkan klien-klien dari perusahaan menyukai transgender, karena dianggap luwes dan mudah bersosialisasi dimanapun ia di tempatkan. "Di lingkungan pekerjaan saya dituntut untuk menjadi diri saya sendiri, dan di kerjaan orang kayak saya tuh bisa lebih luwes sih orang-orang kayak saya, client-client saya pun kepengennya sama orang-orang transgender. Karena transgender tuh ke lingkungan cowok bisa masuk ke lingkungan cewe bisa masuk, ke lingkungan ibu-ibu oke, ke lingkungan bapak-bapak bisa bercanda. Ternyata kita nih ga bisa di pandang sebelah mata." (Firman, November 2020).

Batara tidak mengambil pusing dengan banyaknya orang yang tidak menyukai kaum transgender. Batara melakukan apa yang dia anggap menyenangkan. Adik dari Batara pun menyetujui apa yang kakaknya lakukan.

Proses penerimaan kaum transgender inipun terjadi kepada Jihan narasumber E. Pada awalnya narasumber mengikuti kegiatan pada salah satu organisasi yang bernama Yifos, organisasi lintas iman yang membahas isu ragam gender dan seksualitas, dan di dalamnya memiliki anggota yang beragam. Ketika bertemu dan melakukan interaksi, narasumber merasa kaum transgender sama saja, hanya butuh proses untuk menerima mereka. "Kalau misalkan kamu menolak transgender, sebenarnya anda menolak apanya? Apa kamu pernah berjumpa dengan mereka? Apa kamu pernah berinteraksi dengan mereka? " (Jihan, desember 2020)

Narasumber E ini juga mengatakan, "memang yang lebih banyak di potret di Alquran itu kan laki-laki dan perempuan aja, tapi sebenernya ada gender ketiga yang di sebutkan di Alquran tersebut". Surat yang dimaksud oleh narasumber E adalah surat An-Nur ayat 31. 
Kedua narasumber juga merasa jika urusan ibadah adalah urusan mereka dengan Tuhannya. Diterima atau tidaknya doa seseorang, hanya Tuhan yang memilih. Banyaknya stigma negatif pada transgender membuat narasumber A dan C lebih memilih untuk beribadah di rumah ketimbang ke tempat ibadah.

\section{Eksternalisasi}

Proses eksternalisasi menurut Dharma (2008) adalah dimana individu melakukan penyesuaian atau adaptasi dengan kebudayaan sosial dan kultural disekeliling mereka. Kebudayaan sosial dan kultural inilah yang disebut sebagai tatanan sosial atau kontestasi sosial yang muncul dari produksi manusia secara kontingen.

Proses eksternalisasi yang dijalani oleh Firman selaku narasumber A, dimana ia harus menyesuaikan dan beradaptasi dengan kebudayaan sekelilingnya bisa dibilang cukup mudah. Proses ini dialami dan dimulai oleh Firman dimana awalnya ia menyadari bahwa jati dirinya ialah seorang transgender. Awalnya Firman tumbuh besar di dalam lingkungan agama Islam yang dimulai dengan keluarganya. Namun, begitu Firman menyadari bahwa ia merupakan seorang transgender, ia harus menyesuaikan dengan tatanan sosial sebelumnya yang mengatakan bahwa transgender adalah suatu hal yang buruk.

\section{Objektifikasi}

Proses objektifikasi seperti dijelaskan oleh Berger dan Luckmann (Dharma, 2018) adalah dimana individu berinteraksi dengan tatanan sosial yang sudah dilembagakan atau sudah terinstitusionalisasi. Pengetahuan terkait dengan lembaga sosial ini dapat dipelajari dalam tahap teoritis melalui kaidah sosial, moral masyarakat, kalimat kebijaksanaan, nilai-nilai yang dianut, kepercayaan, mitos, dan lainnya.

Setelah melakukan penyingkapan diri melalui proses eksternalisasi kepada keluarga dekatnya, narasumber Firman pun melakukan interaksi dengan tatanan sosial yang sudah terinstitusionalisasi, yakni dengan lingkungan sekolah dan

kemudian lingkungan kerja. Beruntungnya untuk Firman, interaksi dengan lingkungan sekolah dan lingkungan kerjanya merupakan proses yang mudah. Temanteman di lingkungan sekolahnya menerima Firman dengan lapang. Begitu pula dengan rekan kerja Firman, mereka menerima kehadiran Firman sebagai rekan kerja yang merupakan seorang transgender.

\section{Internalisasi}

Internalisasi menurut Berger dan Luckmann (Dharma, 2018) Dalam tahap internalisasi, individu sudah memahami dan mengidentifikasi dengan lembaga sosial dimana mereka menjadi anggotanya. Individu tidak hanya berinteraksi dengan lingkungan sosialnya, tetapi juga mengidentifikasi dirinya dengan lembaga sosial tersebut.

Karena proses penerimaan Firman sebagai seorang transgender dilingkungan sosial berjalan dengan mudah, maka dari itu proses internalisasi pun berjalan dengan baik. Firman pun mengidentifikasi dirinya dengann lingkungan sosialnya. Tidak hanya Firman menjadi anggota pasif, namun Firman juga berinteraksi dengan lingkungan sekelilingnya. Ia pun mengidentifikasikan dirinya sebagai bagian dari lingkungan sekolah dan lingkungan kerja tersebut. 


\section{Transgender}

Menurut Sinyo (2014:12), waria adalah wanita pria yang dulunya dipanggil wanita-adam. Sebutan waria mewakili istilah transgender juga di Indonesia. Ada juga yang menyebut transgender dengan kata "banci" karena laki laki berpenampilan dan berperilaku layaknya seorang perempuan.

Narasumber Putra, juga transgender, menyatakan bahwa ia menyadari bahwa ada perubahan dalam dirinya ia mengetahui perubahan tersebut sejak beberapa tahun belakangan ini. Ia merasa berbeda dengan lainnya. Hingga ia memutuskan untuk melakukan transgender terhadap dirinya.

Narasumber Andre, adik dari Putra, mengungkapkan bahwa ia awalnya terkejut dengan apa yang dilakukan Putra namun perlahan ia mendukung apa yang dilakukan adiknya tersebut.

Sedangkan narasumber Batara, merasa cukup rumit menghadapi keluarganya. Namun seiring berjalannya waktu keluarga Batara juga mulai menerimanya. Perubahan tersebut merupakan kodratnya yang harus menerima.

\section{Masyarakat beragam Islam}

Menurut Mahmud (2018) masyarakat adalah sekelompok manusia yang terjalin erat karena system tertentu, tradisi tertentu, konvensi, dan hukum tertentu yang sama, serta mengarah pada kehidupan yang kolektif. Masyarakat sendiri memiliki sikapnya.

Narasumber A, Putra bisa lebih bebas bergaul dibandingkan dengan narasumber $\mathrm{C}$, Batara. Batara lebih memilih untuk beribadah di rumah dan tidak mengikuti organisasi apapun dan bersosialisasi dengan lingkungan yang lain selain teman temannya. Hal ini berbeda dengan Putra, meskipun tidak memiliki organisasi apapun tetapi ia bersosialisasi di kantor dan sangat dekat dengan lingkungan sosialnya. Lingkungannya di kantor bahkan menyuruh Putra untuk menjadi diri sendiri, atau menerima kondisi Putra apa adanya.

Di Indonesia dengan adat budaya timur yang sangat kental dengan normanorma sosial akan memberikan sanksi sosial kepada individu yang berperilaku menyimpang dengan cara penghinaan bahkan pengucilan di tengah tengah masyarakat (Bulantika, 2017:164).

\section{Simpulan}

Setelah melakukan penelitian penulis menyimpulkan beberapa hal dalam penelitian ini adalah:

a. Stigma negatif masyarakat kepada kaum transgender masih sangat kuat. Stigma itu berdasarkan adat ketimuran yang kental dan faktor agama

b. Transgender masih sering menutup diri dari lingkungan sekitar atau organisasi-organisasi masyarakat dan hanya membuka dirinya pada orangorang atau kelompok tertentu.

c. Dengan adanya pertemuan dan interaksi secara berkala, maka orang akan bisa menerima transgender dengan melewati prosesnya.

d. Masyarakat mengganggap bahwa transgender adalah kelainan atau penyakit.

e. Proses penerimaan masyarakat kepada kaum transgender berbeda-beda tergantung pada pribadi masing-masing masyarakat dan tingkat pengetahuan tentang transgender. 


\section{Ucapan Terima Kasih}

Terima kasih kepada seluruh pihak yang telah mendukung dan membantu penulis dari awal hingga penyelesaian penelitian ini, khususnya kepada Fakultas Ilmu Komunikasi Universitas Tarumanagar.

\section{Daftar Pustaka}

Berger, P. L., Parera, F. M., \& Luckman, T. (1990). Tafsir Sosial Atas Kenyataan: Risalah Tentang Sosiologi Pengetahuan.

Moleong, Lexy J. (2017). Metodologi Penelitian Kualitatif. Bandung: PT Remaja Rosdakarya. Remaja Rosdakarya.

Nazir, Moh. (2013). Metode Penelitian. Bogor: Ghalia Indonesia

Sarosa, Samiaji. (2017). Penelitian Kualitatif: Dasar-Dasar. Jakarta: Indeks.

Sinyo. (2014). Anakku Bertanya Tentang LGBT. Jakarta: Elex Media Komputindo Sujarweni, Wiratna. (2019). Metodologi Penelitian. Jakarta: Pustaka Baru Press.

Sulfan Akilah Mahmud. (2018). Konsep Masyarakat Menurut Murthada Muthahhari. 